\title{
Population and poverty: A review and restatement
}

\section{Geoffrey McNicoll}

Population Council

Follow this and additional works at: https://knowledgecommons.popcouncil.org/departments_sbsr-pgy

Part of the Demography, Population, and Ecology Commons, Family, Life Course, and Society Commons, International Public Health Commons, and the Urban Studies and Planning Commons How does access to this work benefit you? Let us know!

\section{Recommended Citation}

McNicoll, Geoffrey. 1997. "Population and poverty: A review and restatement," Policy Research Division Working Paper no. 105. New York: Population Council. 


\section{Population and Poverty: A Review and Restatement}

Geoffrey M cNicoll

1997 No. 105 


\title{
Population and Poverty: A Review and Restatement
}

\author{
Geoffrey McNicoll
}

Geoffrey McNicoll is Senior Associate, Policy Research Division, Population Council, New York, and Professor, Research School of Social Sciences, Australian National University, Canberra.

This paper was prepared under a grant from the United Nations Population Fund. Comments by Richard Leete and Cynthia Lloyd are acknowledged. 


\section{Abstract}

Worldwide in the 1990s over one billion persons are estimated to have a purchasing power of below a dollar per day, the conventional demarcation of "absolute poverty." Other dimensions of poverty, extending beyond income measures to encompass a person's broader capabilities and social functioning, are less empirically accessible. Poverty is commonly thought to be associated with high fertility and rapid population growth (regionally, South Asia and Africa have the highest poverty rates), but that view finds little support in the extensive statistical research literature on population and poverty. However, a clear-cut depiction of such an institutionally contingent relationship is not to be expected. Economy-wide effects of population change on poverty can be traced through direct changes in distributional outcomes and through effects resulting from changes in rural and urban environments and social organization. The indirect links are complicated by problems of characterizing the urban informal sector and by the relocation of poverty through migration (and its recomposition through economic mobility). Analytical difficulties arise in stipulating ceteris paribus conditions against which to assess demographic influences. Stylized models can show how certain patterns of social structure and economic transfers in a society sustain resilient "equilibrium trap" situations that generate adverse demographic and poverty outcomes. Although neither fertility nor poverty is usefully regarded as a policy instrument, there are policy measures that impinge on both. The familiar examples of these are programs in education, health, and family planning. Policies in the economic and political domain may be equally or more important. The developmentalist strategies behind many of the strongest economic growth performances of recent decades, albeit contentious on some other grounds, have been associated with poverty alleviation and fertility decline.

This material may not be reproduced without written permission from the author. 
In the mid-1990s the population growth rate of the world's less developed regions (in the UN's designation, comprising some four-fifths of the total world population) is about 1.7 percent per year, well below its $1960 \mathrm{~s}$ peak of 2.5 percent. Average fertility, which was around 6 children per woman in the 1960s, has fallen to near 3, its lowest level ever, and continues to decline. For many countries that have experienced these demographic trends, questions about the consequences of rapid population growth for society and the economy might appear to be no longer matters for urgent investigation. They could be left to more leisurely deliberation by social and economic historians: still able to arouse heated debate but with answers that are of diminished import for public policy and human welfare.

Several factors should give pause to any such relegation. First, the demographic expansion implied by the projected future growth rate trend in the less developed regions is roughly another doubling of population, an additional 4 billion or so people to be accommodated, most of them coming in the next three decades. Second, modest region-wide or country-wide average population growth rates often obscure much faster changes in the sizes of particular population categories, with effects that may be very substantial. Notable among such categories would be the older age groups and the populations of cities. Third, there is a section of the less developed regions, namely the UN's category of "least developed," where demographic conditions of the 1960 s or even earlier still prevail. The 10 percent of the world's population contained in the least developed countries amounts to 600 million people. These countries combine rapid population growth (2.6 percent per year) and rates of economic growth that for several decades have left per capita incomes virtually unchanged (averaging about $\$ 1000$ per year in purchasing power terms in the mid-1990s). For them, population issues retain all their former urgency. 
The issue I am concerned with here is the relationship between population growth and poverty. Surprisingly to those who have only casual knowledge of research in the area, this relationship is neither obvious nor well established. Simple economic arguments would suggest that rapid population growth worsens poverty. Population growth holds down returns to labor relative to capital and other factors of production, depressing wages and worsening the income distribution. Or, if we picture development in terms of an initially small but expanding modern sector within a larger, backward economy, population growth swells the traditional and informal labor force, and delays the time at which modern-sector capital accumulation exhausts the supply of subsistence-level workers. Yet such pieces of theory do not suffice to demonstrate a negative effect. In more elaborate models and in the real world things are more complicated. Time-lags, feedbacks, nonlinearities, and reverse causation enter the picture, as do the institutional practices through which societies mediate among competing claims on the social product. For example, rapid population growth may be a consequence of advances in health, signaling broad-based welfare improvement; economies may expand rapidly with scant regard for equity, but nevertheless show plummeting fertility levels; or societies may be in such economic disorder that continued impoverishment coexists with virtually zero population growth.

These complications explain the hesitant way in which the link between population growth and poverty has been summarized in the recent research literature. The dominant tone is caution and uncertainty in the face of a complex relationship. There is little in this literature to support a strong poverty-based rationale for reducing fertility. The most that the 1992 UNFPA Consultative Meeting of Economists could conclude on the matter was that 
"[t]he causal links between population growth and absolute deprivation are not well understood.... Research has not established a strong causal link running from high fertility to poverty" (United Nations Population Fund 1993: 50-51). World Bank economist Lant Pritchett (1997: 51) is brusquer: solid evidence that population growth is "a cause or even an exacerbating condition of poverty" cannot be given "because there is none."

Nevertheless, while acknowledging the complexity, it is likely that most social scientists would accept that there is a connection between population growth and poverty. In particular, achieving lower fertility, at least in some circumstances (probably including those of most of the world's poorest countries), is likely to help alleviate poverty. The reverse relationship - the effect of poverty alleviation on fertility reduction-is also widely accepted. Hence, for instance, the Programme of Action of the 1994 International Conference on Population and Development in its section entitled "Population, sustained economic growth and poverty" (\$3.10-3.22) asserts that efforts to slow population growth and to reduce poverty are mutually reinforcing.

The situation in which common-sense views about a particular consequence of demographic change rest on an inconclusive body of research is unfortunately all too familiar. It underlies the so-called revisionist argument that holds population growth to be a comparatively marginal factor in the development process. But while simple conclusions on population and poverty are not to be expected, no implication of marginality should be drawn. Complexity does not imply net inconsequence.

In this review I shall sketch enough of the details of the populationpoverty relationship to make clear why it is not amenable to a one-sentence summary, but with no ambition of presenting a full-fledged account of the 
subject. My aim, rather, is to highlight the features that should plausibly enter a policy-relevant restatement of the relationship. The definitional problems that surround the term "poverty" are a necessary starting point. No single definition encompasses all the connotations of the term. Hence, to avoid truncating the study at the outset we have to carry along a cluster of concepts, ranging from the highly concrete to the quite intangible. The main part of the review explores macro- and local-level aspects of the relationship. There are many ways in which population growth can influence economic and social outcomes in general and poverty in particular, connections that work through a society's institutional and cultural make-up, its resource endowments, and its natural and built environments. Often these involve situations in which individual decisions or localized actions, rational within their immediate context, generate external effects that harm others in the society. The structural conditions under which such externalities tend to persist are an important topic for investigation. Finally, I discuss the policy implications of these observations and findings.

\section{Meanings ANd Measurement of Poverty}

At the start of the Handbook on International Poverty Research, Else Øyen (1996: 3-4) characterizes poverty research as "a field where neither the concepts and the methodologies, nor the theories are precise enough to be useful working tools...." In particular, she accuses researchers of using "nonsensical poverty measures formulated in developed countries for another time and another context."

There are indeed definitional problems, but this is to overstate them. The difficulties lie less in the fuzziness or nonsensical nature of measures 
than in the fact that there are a number of different concepts, each of which can be termed "poverty," each appropriately measured in its own way. A single definition does not suffice.

Baulch (1996) presents a simple array of these poverty concepts. Most elementary is the measure of deprivation in terms of the level of a person's private disposable income or consumption. This can (and no doubt should) be expanded to include use of common-property resources and government transfers and services. It can be further elaborated to include measures of private assets that can be transformed into consumption use in times of crisis-a means of capturing individual economic vulnerability. These are all more or less tangible components that can be expressed in monetary terms; but there are also intangible factors that bear on poverty. Obligations from kin or community that can be called on to smooth out consumption deficits make up an informal category of assets that are embedded in particular patterns of social relations. Even more intangible, but important in the subjective perception of poverty, are deprivations on the dimensions of dignity and autonomy: lack of self-respect and perceived powerlessness.

Poverty in consumption terms can be gauged through standard survey instruments. There are well-known practical difficulties in obtaining accurate responses on income and assets, and intricate problems (conceptual as well as empirical) in dealing with intrahousehold allocation. Both of the two major international demographic survey-taking enterprises, the World Fertility Survey and the Demographic and Health Surveys, made deliberate decisions not to explore the economic status of households in their central questionnaires, on the grounds of the complexity of the subject and the likely unreliability of responses. The reluctance of the WFS and DHS to explore 
economic issues was a missed opportunity to expand the empirical basis for research on population and poverty. However, other household survey programs have not been deterred, notably the elaborate series of Living Standards Measurement Surveys undertaken by the World Bank.

The intangible dimensions of poverty raise rather more intractable measurement problems. They call for investigation of resources and social relations from the inside of a society, to spell out how people's behavioral freedom and opportunities, as they see them, are constrained. Social pressures can operate as stringently as legal prohibitions to limit choice in economic and social behavior; internalized restraint—as in the so-called culture of poverty-may have the same effect. Anthropological methods would be needed to properly assess these factors, but such methods are time consuming and their findings lack comparability. For rapid appraisals of subjective poverty with more standardized comparative content, an interactive technique known as Participatory Poverty Assessment (PPA) can be called on (see Shaffer 1996).

\section{Absolute poverty}

Absolute poverty is a term that came into vogue in Robert S. McNamara's tenure as World Bank president. It has the connotation of "utter poverty" and seems sometimes to be used in that sense. Thus McNamara (1995: 5) sees it as describing "those living, literally, on the margins of life. Their lives are to such an extent characterized by malnutrition, illiteracy, and disease as to be excluded from any reasonable definition of human dignity." But absolute poverty also has a straightforward, statistically accessible meaning. It refers to "the inability to attain consumption levels which would be 
deemed adequate in only the poorest countries" (Ravallion et al. 1991: 346), and is usually measured by a per capita real income below a fixed poverty line. It stands in contrast to relative poverty. Countries set their own poverty lines, influenced to some extent by their average consumption levels. Among a number of poor countries, including some large ones like Indonesia and Bangladesh, the line turns out to be very similar when gauged by purchasing power: around US $\$ 30$ per month, or $\$ 1$ per day, at 1985 prices. This standard is used in the numerous World Bank poverty studies of recent years.

Worldwide in the mid-1980s, according to Ravallion et al. (1991), there were 1.1 billion people in developing countries below a "dollar per day" poverty line, and 700 million below a $\$ 23$ per month line (corresponding to India's standard) that these authors denote the "extreme absolute poor." These are the figures cited in the 1990 World Development Report, which was focused on poverty. Estimates from a later, more elaborate study by the same World Bank group, drawing on more recent and fuller survey data on consumption expenditures, are given in Chen et al. (1994). Equivalent data from the UN Development Programme's 1997 Human Development Report, referring to 1993, are given in Table 1. They show a total of 1.3 billion absolute poor.

Differences in data sources and aggregation procedures can yield large variations in these estimates. For example, the poverty rate for sub-Saharan Africa, shown as 39 percent for 1993 in the 1997 Human Development Report (and virtually the same rate for 1987 in an earlier $H D R$ ), is given as 53 percent for 1990 in Chen et al. (1994: 370). Again, the Human Development Report's East Asia poverty rate is largely governed by China (the 26 percent average for the region drops to 14 percent if China is excluded), but national income data and purchasing power adjustments for China are especially problematic. 
Table 1 Numbers and percentage of population in absolute poverty for a poverty line of $\$ 1$ per day consumption expenditure (PPP\$ at 1985 prices) by major region of the developing world, 1993

\begin{tabular}{lcc}
\hline Region & $\begin{array}{c}\text { Numbers } \\
\text { (millions) }\end{array}$ & $\begin{array}{c}\text { Percentage } \\
\text { of population }\end{array}$ \\
\hline South Asia & 515 & 43 \\
East Asia & 446 & 26 \\
Sub-Saharan Africa & 219 & 39 \\
Arab States & 11 & 4 \\
Latin America* & 110 & 24 \\
All developing countries & 1301 & 32 \\
\hline
\end{tabular}

* poverty line of $\$ 2$ per day

Source: United Nations Development Programme 1997, Table 2.1.

The numbers or proportions of people in poverty is termed a headcount index. This does not describe the depth of that poverty, which is clearly relevant to a quantitative assessment. For the latter purpose, a supplementary measure, the poverty gap, is often used. The poverty gap is the aggregate income shortfall of all those below the poverty line as a proportion of aggregate consumption - i.e., in a notional interpretation, the minimum fraction of consumption that would have to be reallocated to eliminate absolute poverty.

\section{Alternative survey-based measures of poverty}

Survey data bearing on poverty are not confined to household income and consumption. Examples of other survey-based information would include:

- Health or nutritional indicators, such as anthropometric measures of nutrition or assessments of parasite load. These data are more intrinsically tied to individuals than are pro-rated shares of house- 
hold income, thus circumventing the problem of imputing intrahousehold allocation; but they may reflect other causes in addition to poverty. Dasgupta (1993: 81-87, 90-97) gives a lucid summary of the measurement problems.

- Infant and child mortality rates. Mortality rates correspond to negation of life chances in a literal sense. (They are of course not meaningful for individual families or for small population groups.) Acknowledging that mortality outcomes are sensitive to comparatively inexpensive government interventions in infrastructure, public health, and education is not to lessen their link to poverty, broadly construed, but merely emphasizes that some dimensions of poverty may be fairly easily remedied.

- A broader measure of population health-or its complement, the "burden of disease"-would cover both mortality and illness or disability. An index of this kind is the so-called disability-adjusted life years (DALY), which combines years lost through premature mortality and years lived in an impaired state owing to disease or disability. The latter years are weighted at levels between life and death, depending on the seriousness of disability; other weights used in the aggregation incorporate time-preference and social valuations of life at different ages-complexities that are no doubt necessary, but lessen the index's intuitive appeal. A sample result is that in 1990 sub-Saharan Africa suffered 580 DALYs per 1000 persons (or person-years), whereas the developed countries incurred only 100. (See World Bank 1993; Murray and Lopez 1996.) Population health, however, includes major health effects of behavioral 
and chance factors (smoking-related illnesses, for instance) that are not primarily linked to poverty. A DALY-like index that reflected health outcomes of poverty could presumably be designed, and might prove instructive.

- Indicators of housing quality, access to clean water, etc. Many national sample surveys, such as India's NSS or Indonesia's SUSENAS, from time to time collect housing quality data, especially information on number of rooms, construction materials (roof, walls, floor) and floor space, source of drinking water, electrification, and type of latrine. Ownership of consumer durables (bicycles, radios, etc.) is also given in some household surveys. Such data permit construction of ad hoc poverty indexes.

An effort to construct a composite index of poverty that can draw on survey data but that extends beyond income criteria is described by Anand and Sen (1997) and employed in the 1997 Human Development Report. The Anand-Sen human poverty index (HPI) is made up of five components: the proportion of deaths below age 40, the proportion illiterate, the proportion without access to safe water, the proportion without access to health services, and the proportion of underweight children below age 5. (The last three are averaged to give a single proportion that is said to describe deprivation in overall economic provisioning.) Clearly, the HPI is heavily weighted toward basic health outcomes, and would correlate strongly with a summary measure of mortality - the more so as health and literacy tend to be associated. It follows that the poverty rates it yields differ from those based on income data. Thus the Human Development Report now distinguishes "human poverty" from "income poverty." Looking at the data across broad re- 
gions, it notes particular divergences between the two kinds of poverty "in the Arab States, where income poverty was reduced to 4 percent by 1993 but human poverty was still 32 percent, and in Latin America and the Caribbean, where human poverty has been reduced to 15 percent but income poverty is still 24 percent” (United Nations Development Programme 1997: 23).

\section{Capabilities and functionings}

In his book Poverty and Famines, Amartya Sen (1981) pioneered a major shift in understanding famine by stressing the role of a collapse of "entitlements" to food. In the major famines he studied, Bengal in 1943, Bangladesh in 1974, and Ethiopia in 1973, the cause was not an aggregate shortage of food but the inability of major segments of the population to establish entitlement to it. In Bengal and Bangladesh, depressed labor demand and rising grain prices made food increasingly unaffordable to rural wage laborers; in Ethiopia, pastoralists lost much of their trade-entitlement to food with the death of their livestock. Enhancing security against famine thus calls for an understanding of food entitlements-through study of the nature and distribution of property rights and the structure of labor and product markets - as much as for efforts to raise aggregate food supplies.

In the same study and in later writings (e.g., Sen 1990, 1992), Sen discusses "the problems of establishing command over commodities" in more general terms. This is what he calls the "acquirement problem." Command is established by use of a person's own endowments (of physical and human capital) in production and exchange and by any of the various channels of acquisition that are open. Social capital-resources inherent in networks of kin and other kinds of obligational relationships-offers another potential 
source of command over commodities. In a socialist economy or a welfare state some entitlement to commodities may also be conferred by virtue of citizenship or legal residence, ensuring attainment of a prescribed minimum consumption level. (The usual implicit assumption is that the channels used are legal; however, command can of course be acquired through extra-legal means-by force, deception, or theft.) The shift in emphasis is from income or possessions to "functionings" or "capabilities." Poverty, in this discourse, is inadequacy of the command needed to achieve a minimal level of functioning.

This perspective might be criticized as tending to divert attention from simple poverty-reduction measures like raising domestic food productionwhich is associated with increased nutrient intake, lower mortality, and higher labor productivity among the poor (see Timmer 1994). Undoubtedly, however, the factors that it emphasizes are properly seen as dimensions of poverty and should somehow be made empirically accessible - though that is no easy task. The "capability poverty measure" (CPM), introduced in the 1996 Human Development Report, may have been an attempt in that direction, but its three ingredients seem not well described as representing "capabilities": the proportion of under-five children who are underweight; the proportion of births attended by a trained health worker; and the rate of female illiteracy. (See United Nations Development Programme 1996: 27-28.)

\section{Life cycle poverty}

Research in both developed and developing countries has found substantial movement into and out of poverty. An apparent stability of income distribution across families can disguise a rapid turnover in the identity of individual families falling in any particular economic category. For the US, 
this was one of the principal findings of the elaborate Michigan Panel Study of Income Dynamics (Duncan 1984: 10). In smallholder agrarian settings, land sales are a sensitive indicator of economic mobility: Cain's (1981) analysis of such data for Indian and Bangladesh villages shows how natural disasters lead to distress sales of land in the absence of effective credit institutions or public relief employment. The Bangladesh case, with such devices as yet poorly developed, exhibited substantially greater economic mobility-especially downward mobility. The "environment of risk" faced by small landowners is itself a manifestation of poverty.

Families may of course move into or out of poverty for simple demographic reasons - as their ratio of economically active members to dependent members changes over time. The empirical observation that poor households (where poverty is gauged by per capita household expenditure) tend to be larger than rich ones is in part attributable to the dependency burden of young children (Visaria 1980: 196-197; total household expenditures are positively associated with household size). However, relationships between household structure (or family structure) and poverty are intricate and permit few uncontested generalizations. As Lloyd (1995: 26) puts it, the poor "are found in households of every structure.... [T]here is nothing inherent in a household's structure that predicts poverty or, alternatively, promises resource adequacy."

It is possible for the numbers of the poor to rise with population growth at the same time as most of the original poor have become better off. Migration is an obvious circumstance in which this could happen, but it is not the only one. Samuel Morley (1981) notes the implications for assessing poverty-reduction measures through intertemporal comparisons, where the poor 
in the final period may include many different people from the poor at the outset: "If we are interested in knowing how the poor of the base period fared over time, and surely this is what the whole debate over trickle-down is all about, the real income growth rates of the bottom $k$ th percentile will not tell us" (p. 287).

The other extreme to families that are only briefly in poverty are those for whom poverty is an intergenerational phenomenon. Poverty that is "transmitted" from one generation to the next in a family, through constriction of educational or other opportunities for children or even through effects of nutritional deprivation, represents a particularly serious category from the standpoint of human welfare and social policy. The literatures on the "culture of poverty" in poor countries and the "underclass" in rich ones are concerned with this potential intergenerational transmission and how it might be interrupted. The topic is discussed below.

\section{Subjective perceptions of poverty}

How do poor people themselves describe their economic status and changes in their economic circumstances? Jodha (1989: 182) has investigated this question for members of poor rural households in India. He consolidates the responses into the following categories:

- degree of reliance on patrons or landlords for employment, inputs, marketing of produce, off-season loans, etc.;

- degree of dependence on low-status jobs;

- options for geographic mobility and degree of liquidity;

- consumption patterns and practices, especially food quality and variety; 
- household asset position, especially housing characteristics and possession of consumer durables but also including access to common-property resources.

In Jodha's own village study, an income-based measure of poverty shows an increase in poverty over two decades, but the villagers themselves record some improvement on these other dimensions. Such a divergence is not at all surprising: it merely underlines the impossibility of reducing a complex, multifaceted process of change to a single index.

$$
\text { * * * }
$$

Definitional diversity is not usefully dealt with either by consolidation or by selectivity. It can simply be accepted as a characteristic of this particular subject area. Poverty cannot wholly be captured in income terms. But we should resist equating poverty with all kinds of disadvantage. Thus, it is worth preserving the distinction between poverty and health indexes-against the tendency noted above in the operationalization of the "human poverty" concept. It may also be worth guarding against built-in assumptions about appropriate government roles in provision of health services and education that come with too complete a distinction between human- and income-poverty. That public-sector provision of such services offers one way to reach the poor does not mean that it is necessarily a superior route to simple income subvention or, indeed, to plain economic growth.

\section{MACRO-LEVEl POPUlation-POVERTY CONNECTIONS}

Elementary economics tells us that abundance of labor in an economy will make for low wages relative to rents. It tells us that the faster population 
grows, the greater the requirement for investment that simply maintains the level of capital per head-implying less output available for current consumption or for investment in raising capital per head (capital deepening) and thus for future consumption. As Solow (1970: 29) put it, "An economy that must in a steady state support a more rapidly growing population will support it at a lower standard of consumption, given the savings rate." These simple propositions underpin the intuitive expectation that rapid population growth will tend to produce higher levels of poverty than low population growth.

Nevertheless, the economic case for population growth generating poverty has had a chequered career over recent decades. Technological change and human capital, not material resources, came to be seen as the major factors in explaining economic growth, readily able to overcome diminishing returns to labor. Neoclassical growth theory, the ruling theoretical paradigm, for the most part ignored issues of labor absorption and unemployment. On its steady-state growth paths, the economy was expanding exponentially at the rate of growth of the labor force plus that of labor productivity. Population, in this stylized view, became little more than an index of the scale of the economy, poverty a marginal phenomenon; neither held much theoretical interest.

In the 1960s development economics emerged as a field in its own right, distinct from the theory of economic growth. In it, population for a time regained a substantial place, seen as influencing overall economic outcomes and, in particular, affecting poverty. This was the heyday of dual economy models, in the major variant of which development was envisaged as an expanding modern sector drawing on the labor and savings of a "traditional" agricultural (or urban informal) sector (see Lewis 1954 and Fei and 
Ranis 1964). Under successful development, the surplus labor is eventually exhausted, after which wages progressively rise on an economy-wide growth path. While actual labor market structures and wage determination processes are far more complicated than such models assume, it seemed possible to roughly locate the period over which the labor surplus (in Lewis's apt example, household servants) dries up. This "turning point" when dualism is eliminated was likely also to mark a decisive phase in poverty reduction, beyond which poverty would be associated with particular sources of disadvantage rather than characterizing substantial parts of the labor force. Rapid population growth would retard the time at which that point was reached.

The independent status of development economics was always tenuous, however. The institutional obstacles it gave salience to were often shown to be mirages, vanishing under price reform and other standard economic recipes. Clive Bell (1987), in The New Palgrave, writes of the subject being "drawn back into the fold" of micro- and macro-economics proper. Population went with it. Even dualism could be restated in fully neoclassical terms, with population effects reduced to near inconsequence (as, for instance, in Kelley and Williamson 1974). The 1986 report on population and economic growth of the National Research Council, summarized by its co-chair as "support[ing] the conclusion that population growth has little or no negative effect on economic development" (Johnson 1994: 524), accepted this reintegration and appeared to confirm the inconsequence. The "new growth theory" of the 1980s and 1990s, with its role for increasing returns and historical fortuity, has little to say about population size.

An intriguing development in the 1990s has been the second thoughts about the effects of population growth that have emerged from cross-sec- 
tional analysis applied to 1980s data (e.g., in Kelley and Schmidt 1994) and from a close look at the strong economic performance of East Asia in the 1970s and 1980s. In the latter case, the early fertility decline and consequent fall in youth dependency in most of these countries is now seen by some economists, echoing the Coale-Hoover argument, as contributing to their surge in investment (see Higgins and Williamson 1997). Significantly, East Asian poverty rates also fell sharply over this period. However, the finding is still circumstantial: there are various competing accounts of the "East Asian miracle."

The prima facie empirical case for the unimportance of population has come from cross-country analysis. Scatter plots of countries on axes representing population growth rates versus per capita GNP or more refined indexes of income-poverty are famously unpersuasive. High-population-growth countries are nearly all poor, but the association is anything but tight. (It is certainly negative, but that is hardly surprising given the overall demographic contrast between rich and poor countries.) The same opaque relationships can be reproduced using numerous pairs of demographic and economic variables (McNicoll 1984: 211).

Both mortality and fertility contribute to the confused picture (migration does too, in the case of some outliers). There are steep income effects on mortality at low incomes — see Preston (1980) — and few exceptions to low fertility at high incomes, but wide variations in each over a broad middleincome range. Poverty measures with substantial demographic content, like the Human Poverty Index, are definitionally linked to mortality. Considerable noise is added to this and analogous bivariate relationships by the variation among countries in political and economic systems and social institutions-which together affect both economic performance and capacities to influence demographic outcomes. 
Multivariate analysis does little to clarify the matter. Theoretical support can be found for various causal paths between population and poverty, in both directions. Moreover, the underlying models must assume cross-country regularities in development patterns that are belied by the actual diversity among countries. Not surprisingly, no sharp picture emerges. The careful aggregative modeling by Rodgers (1984) concludes on the overall slightness of the adverse population growth effect. In a later piece he writes: "[T]here is little empirical evidence to support the proposition that population growth is a major constraint on the alleviation of poverty.... Population growth is both a cause and a consequence of poverty, and unravelling the pattern of causation may be an almost hopeless task" (Rodgers 1989: 9). Ahlburg (1996), extending an analysis of poverty change by Squire (1993), finds no association of population growth with changes in poverty. Lipton (1997) is an exception, reporting a "large" positive effect of fertility on subsequent poverty in a 28-country analysis. Timmer (1994: 262) comments on population-poverty research that "because of path-dependency and important dynamic feedback effects, cross-sectional evidence can offer only limited insights."

Is aggregative analysis then of no help in illuminating the populationpoverty relationship? That would be an undue concession to agnosticism, on two grounds. First, an explanatory calculus that finds little to be explained may simply be unsuited to the analytical task. Poverty manifestly remains in many countries; economies often regress; not all dysfunctional institutional structures vanish or costlessly adapt as a result of getting prices right. Our calculus needs to accommodate these elements and outcomes. Second, a murky cross-sectional picture, as we have noted, does not prove the absence of a relationship. If cross-country studies tell us little, we are thrown back on 
single-country analysis or on cautious and selective use of country comparisons. The difficulties of dealing with counterfactuals-investigating what would have happened had conditions been different in specified ways - then have to be faced, but that task is familiar to historians and differs mainly in degree from the one routinely encountered in doing sensitivity analysis.

\section{Social and environmental settings of population-poverty relationships}

In any economy, adding more people has a complex and ramifying set of welfare effects. These effects depend on technological and institutional features of that economy, on its natural resources, on the social and cultural makeup of the surrounding society through which claims on the social product are allocated, and not least on the characteristics of the additional people. Efforts to model effects of population growth must ignore most of these possible sources of variation in outcome (usually by assuming other things equal) and drastically simplify the rest. Of course, this is a state of affairs met with in modeling any aspect of social change, but it is important to keep it in mind.

For national populations, the implicit comparison against which effects of rapid population growth are gauged would usually be the counterfactual case in which growth is reduced because fertility has fallen. The rapid growth would presumably have resulted from an earlier reduction of mortality — clearly in itself a welfare improvement. High fertility may or may not include a significant component of "unwantedness" that would make fertility reduction in itself a contribution to (parental) wellbeing: survey responses would suggest that it does - at least for the mother-but the matter

remains controversial. For macro-level analysis, a conservative assumption 
would be to ignore the difficulties of unwantedness estimation but to acknowledge that actual fertility levels respond to social and economic change in fairly predictable ways.

For population growth that is a consequence of migration rather than natural increase, the welfare calculation should presumably consider changes in each of the three groups concerned: the migrants, the receiving society, and the society of origin.

The labor surplus models mentioned earlier directed attention to the process of labor absorption - and, by implication, poverty alleviation-in economic development. Thus, Portes and Benton (1984: 589) could write that "[o]ne of the few points of agreement in the area of development is that poverty is a direct result of unemployment or underemployment and, hence, that overcoming poverty requires the mass incorporation of the working-age population into modern industrial employment." But an undifferentiated subsistence sector, especially one primarily identified with agriculture, is an unsatisfactory way of locating poverty and tracing its changing incidence. Further specification of the setting is required, in terms of economic institutions (the labor market and credit systems, and other aspects of production relations); government roles and more general patterns of social organization; and resource availabilities and environmental conditions. In particular, we should be interested in how demographic change impinges on this setting and in exploring its consequent effects on people's command over commodities. While often this specification task must involve investigation of micro-level social, economic, and environmental change (more on this below), some more aggregative empirical observations and modeling directions are also relevant. 
A simple framework for organizing the discussion would identify three routes through which population change may affect poverty. The "direct" one is the population-economy link. The economy, broadly interpreted, incorporates market-based and other institutional means of income (or, more generally, "command over commodity") distribution. Included in those "other" means are contributions to the social wage through the public-sector provision of health, educational, and other services. Poverty outcomes are one part of this overall distributional function. In addition, population change itself, to the extent that it brings about or entails an altered demographic structure of households, may have a simple arithmetic effect on consumption.

The other two routes take account of possible changes in the environmental and social setting. Many population-related environmental changes have effects on poverty. We can write:

\section{$\Delta$ Population $\rightarrow \Delta$ Environment $\rightarrow \Delta$ Poverty}

(where $\Delta$ signifies "change in"). A somewhat distinct triplet would link population and poverty through effects on social organization, though this as yet has been far less researched than the environmental link:

\section{$\Delta$ Population $\rightarrow \Delta$ Social organization $\rightarrow \Delta$ Poverty.}

Poverty, in turn, would often have consequences for both environment and the social order, and environmental change and social (in)stability are themselves sometimes connected. These additional relationships rapidly complicate the picture. Moreover, the $\Delta$ notation leaves ambiguous the matter of contingency: it does not specify (to put it a different way) how the partial 
derivatives are partialed. Thus, to identify any relationship working through environmental change involves making assumptions about social organization-at a minimum, a ceteris paribus stipulation. Analogous assumptions on the environment are required in tracing causal paths through social arrangements.

Poverty links to environmental change (separating urban and rural settings) and to social instability are treated in the remainder of this section.

\section{Poverty and the urban informal sector}

If industrial employment generation fails to keep up with growth in the labor supply, the working-age population backs up in low-productivity activities and all-but-open unemployment-that is, in the usual understanding of the term, in the informal sector. This sector is seen as a kind of labor sump, "a refuge for those unable to find jobs in the modern sector" (Portes 1997: 249). It is not in any sense uniform: this description, emphasizing the range of near-subsistence or illicit activities it contains, is from McNicoll (1984: 208):

[T]here is a fairly clear productivity ladder down which marginal labor force entrants find themselves pressed as their numbers increase in the absence of either an open land frontier or an otherwise expanding economy. ... Any economy offers a wide range of open-entry, low-productivity occupations, for the most part entailing self-employment but with a minimal requirement for working capital. Handicraft production, micro-scale trading and arbitrage, and personal services of all sorts are the main ar- 
eas of this activity, highly visible in most poor countries. . . . Extortion and theft, of course, are direct means of access to product, and clearly open-entry occupations.

In a broadly similar vein, Sachs (1990: 99) describes the Brazilian case as a "process of exclusion and social segregation, creating a huge surplus of underemployed labor in our cities."

But Sachs also notes the intricate organizational structures that develop and the social capital that can be mobilized. The result is "a maze of interconnected labor, service, and goods markets, ranging from organized business to organized crime, a non-market household sector, as well as an incipient non-market social sector based on mutual help." Indeed, the informal sector can be seen less as a labor sump than as a dynamic source of microscale entrepreneurship for the economy. This view first came to prominence in the work of Hernando De Soto (1989), to whom informal economic activity appears as a dynamic response to the institutional rigidities of overregulated or statist economies. Unregulated enterprise, far from being the survival behavior of a near-destitute labor reservoir, becomes the entrepreneurial feedstock of development. The poverty issue does not wholly vanish but is relegated to the status of a comparatively fringe concern. In Portes and Schauffler's (1993: 55) paraphrase of De Soto, "the informal sector is not part of the problem of underdevelopment, but part of its solution."

In any particular case, the two pictures must somehow be reconciled with the single empirical reality. Whatever grass-roots dynamism the informal sector might display, part of that reality for many cities is a physical environment dominated by poorly serviced squatter settlements- 
shantytowns, bidonvilles, and favelas-the environment, for example, that Scheper-Hughes (1992) wrote about in Death Without Weeping. Many cities in the developing countries have been growing at double the rate of natural increase of population: rates of 5 percent per year are common, a doubling time of 14 years. Under those conditions physical infrastructure would be hard pressed to keep pace, even with a booming economy (as, for instance, in China's coastal provinces). With more typical economic performance, the quality of the built environment is virtually bound to fall; public health is likely to suffer along with it. Brockerhoff and Brennan (1998) analyze DHS data on city populations to show the adverse effects of rapid population growth on infant mortality in cities, a link found to be especially pronounced in Latin America.

Plausibly, the two pictures are only superficially inconsistent. Portes and Schauffler (1993) propose such a compromise. Their interpretation calls for a typology of informal activities, recognizing both the dynamism of many microenterprises and the precarious lives of many people in the sector. Some amount of dynamism and off-the-books organization in economic activity and elaborate networks of mutual assistance can coexist with a broad degree of material poverty. How much is hard to gauge: by their nature, estimates of the size of the informal economy, and thus of the incomes of its participants, are error-prone. (Mortality rates, or more general measures of "human poverty," escape this problem for population groups.) The static aggregate situation, however, would be of less interest than the detailed directions of change: whether poverty, however construed, was a diminishing phenomenon along the life cycle of most individuals or whether it permanently identified a substantial subgroup. While this is likely to hinge mainly on the overall pace of 
economic growth, instances where particular social groups face continued exclusion from economic opportunity are not uncommon.

\section{Rural poverty and the environment}

A necessary byproduct of rapid urbanization and declining fertility is a fall in rural population growth. In much of the developing world rural populations will cease expanding within a decade or two; in some countries they have already started to contract. For the natural environment, population growth effects, whatever they may have been, will diminish. (Indirect effects may of course continue: ambitions for self-sufficiency in food production for growing national populations may dictate continued expansion of agricultural areas, often with adverse environmental consequences.) SubSaharan Africa is the main exception to this reversal, with population growth remaining a rural as well as urban reality.

There is of course no simple connection between rural poverty and population growth. This is the terrain on which Malthusian and Boserupian models contend and the location of the original "tragedy of the commons." Moreover, it is not just population numbers that potentially matter: poverty outcomes may be influenced, for example, by disproportionate outmigration from the most economically active age groups. Consider the range of responses to population growth in a subsistence agrarian economy. They might be categorized as follows:

- extension of cultivated area through conversion of pastoral or forested land, or cultivation of steeper slopes and other marginal land;

- intensification of production through improved varieties and inputs, multiple cropping, etc.; 
- population limitation through (voluntary) outmigration or birth control;

- forcible exclusion of part of the population from access to the social product;

- diminished welfare for some or all of the population or increased dependency on outside subventions.

The list is not exhaustive but covers the principal possibilities. It mixes "effective" responses, in which agriculture proves a dynamic growth sector and a potential source of investment for the rest of the economy, and "ineffective" responses that yield poverty, social disorder, and environmental degradation. Commonly, responses would encompass elements of several of these categories, the balance varying over different social groups. The actual outcome in a particular case depends on resource endowments, inherited institutional and cultural practices, the course of political development, competency in public administration and development planning, and some measure of chance. There would usually be winners and losers but a rough consensus could probably be reached on whether rural poverty had risen or fallen. Where there is a net income gain, it is at least theoretically possible for the losers to be compensated so that no one is worse off, either through deliberate intervention or by trickle-down effects.

Consider some instances on the ineffective side. Population growth in nineteenth-century Ireland played an underlying role in creating that region's extreme vulnerability to crop failure, with its outcome at mid-century of starvation and mass emigration. Nepal and the Philippines in recent decades offer pictures of population pressures leading to ecologically unsound spread of upland cultivation, producing severe environmental degradation and 
outmigration - to the Terai and to Mindanao, respectively (see Eckholm 1976, Seddon 1989, and Ooi 1988). In the lowland tropics, even where erosion is not a problem, the soil quality of much newly deforested land falls off sharply after a few seasons, offering little prospect for subsequent intensificationindeed, often ending in abandonment. The case of Brazil is most familiar, with rapid population growth in Amazonia (the migrants coming from elsewhere in the rural sector) producing these outcomes. Bangladesh has witnessed a long process of impoverishment in situ, through plot subdivision and extension of cultivation on to hazardous delta islands, as rural population densities have risen to extreme levels. Sub-Saharan Africa presents notable instances of the breakdown of rural agricultural systems and subsequent impoverishment, but for the most part these do not belong in this category: the environmental outcomes have been byproducts of destruction of social infrastructure, leading to endemic insecurity, population displacement, and heightened mortality.

As with the urban informal sector, the population-environment-poverty link tells only one strand of the rural change story. For example, ecological degradation in Nepal and elsewhere in the Himalayas can be explained in considerable measure without invoking human agency. The deep lowland soils of the northern subcontinent come from eons of heavy but "natural" erosion, leading some alpine ecologists to dismiss "ecocatastrophe" accounts such as Eckholm's as unsubstantiated (see Ives and Messerli 1989). In another exemplary environmental disaster, the apparently irreversible degradation of the agricultural region surrounding the Aral Sea-and the shrinkage of the sea itself — while it has clearly led to widespread rural impoverishment, is almost entirely attributable to drastically ill-conceived plan- 
ning decisions (Kasperson et al. 1995). Again, natural increase of population had little to do with the Brazilian experience of falling incomes of small farmers as landholdings were consolidated and operations commercialized in the 1970s. Both the frontier migration and the extrusion of labor out of the agricultural sector altogether were consequences of this severe contraction in labor demand (see Merrick and Berquo 1983: ch. 4; Wood and Perz 1996).

Deterioration of the natural systems on which agriculture depends, such as watersheds and aquifers, can be potent causes of increased poverty in expanding rural populations. Even if these factors are comparatively stable, however, behavioral responses to rising densities may impede economic progress. The Malthusian model, and its later formalization as the low-level equilibrium trap (Leibenstein 1954, Nelson 1956, and, in modern garb, Becker et al. 1990), are hypotheses about rural populations that encompass this assertion. Some others are discussed below. For the most part, as with other highly abstract models (Boserup's included), they are best seen as stylized perceptions about the world rather than as formulations amenable to empirical testing. Unquestionably the rural populations of Bangladesh or India would be much better off today if they had not more than doubled their numbers over the last few decades: whether or not we describe the outcome as a trap, there must be structural reasons why the society did not follow the path of macro-level rationality. Abstract theorizing about such reasons, however, cannot substitute for historical analysis.

\section{Population growth and the social order}

A potentially powerful macro-level argument linking population growth and poverty derives from the assertion that demographic forces can under- 
mine the social order-and in the limiting case, lead to outright state failure. Political disorder and consequent erosion of social capital can drastically impede routine economic activity. If it persists, it may destroy the institutional — and material — base of production and distribution, generating widespread poverty. Can such a link can be empirically sustained?

Recent writings making a population growth-conflict case include those of Homer-Dixon (1991, 1994), Goldstone (1991, 1997), and, in more popular vein, R.D. Kaplan (1996). The reports issued by the University of Toronto's Project on Environment, Population and Security present a series of country studies that investigate the likely political consequences of emerging renewable-resource scarcities. Population growth is one of the causes of scarcity, migration is often one of the effects. (See, for example, the study of water scarcity in China by Economy 1997.) Goldstone investigates the tensions generated by population expansion under inflexible or maladapting institutions in a series of historical and contemporary contexts.

Environmental scarcity, in Homer-Dixon's usage, can result from change in access to resources or a change in distributive systems as well as from resource depletion or degradation, so that demographic causes would rarely stand alone. In turn, scarcity raises the financial and political demands on governments and reduces their revenues. "A widening gap between state capacity and demands on the state, along with the misguided economic interventions such a gap often provokes, aggravates popular and elite grievances, increases rivalry between elite factions, and erodes the state's legitimacy" (Homer-Dixon 1994: 25).

Drawn-out civil conflict and resulting decay of state legitimacy and capacity would nearly always be accompanied by drastic economic deterio- 
ration. The African examples of Somalia, Liberia, and Sierra Leone are cases in point. (The converse argument, that impoverishment will generate civil unrest, finds relatively little support.) However, conflict does not necessarily lead to impoverishment. For example, the economic impact of a violent change of regime would usually be severe but may be fairly transitory and affect mainly the more capitalized sectors.

The Rwanda experience warrants separate mention. The 1994 mass killings in that country and the civil war and massive refugee exodus that followed have provided grist for many assertions that such a tragedy was almost a predictable outcome of population growth coming up against hard resource constraints. By implication, Rwanda was merely a more immediate and genocidal version of the state failure seen elsewhere. This seems not to have been the case (see Percival and Homer-Dixon 1995, Prunier 1995). Certainly Rwanda had an extraordinarily high rate of population increase (well over 3 percent annually) in the 1970s and 1980s, and rural population densities had reached extreme levels by the 1990s. But Rwanda was a strong state by African standards; the civil war and the regime change that resulted were not at all drawn out. Careful analysis of the 1994 events depicts a more complex set of antecedents, located in a distinctive set of political actors and economic interests. Nevertheless, the demographic saturation of an agrarian economy was an evident background condition that sustained the communal tensions, and continues to do so, even if it did not create them. Explanation on an immediate political level is not inconsistent with a longer-range view that accords significant weight to population change.

Management of development is a comparatively recent expectation of governments. Administrative incompetence and rent-seeking, on the other 
hand, have been perennial expectations. Complaints about them were refrains of the classical economists. In Malthus's explanation of agrarian poverty in the Ottoman Empire, for example, the government's "tyranny, its feebleness, its bad laws and worse administration of them, together with the consequent insecurity of property, throw such obstacles in the way of agriculture that the means of subsistence are necessarily decreasing yearly..." (Essay, 3rd ed., Bk. 1, Ch. 10). Extortionate government rent-seeking, choking off economic growth in its infancy and leaving the effort to be dissipated in population increase, is seen by E.L. Jones (1988) as a repeated story in world history from the ninth to the eighteenth centuries. Jones describes the pattern as a low-level political trap-the eventual twin escapes from which gave rise to the industrial revolutions of Europe and Japan. Partial modern analogues would appear to be common, where persistence of a population-poverty connection turns out to have much to do with a predatory government.

$$
* * *
$$

A sufficient explanation for lack of conclusiveness in international cross-sectional studies of population and poverty is the diversity of environments and institutional settings that are encompassed. Major compositional changes underway in the population, particularly urbanization, might similarly obscure the relationship: the direct effects of population growth are being literally transferred away from rural areas and concentrated in the cities. Urban environments, however, are themselves subject to degradation, both on their intensive margin - the preexisting built environment and physical infrastructure - and on their extensive margin, through expansion of squatter settlements. Poverty in such areas is manifested in low consumption levels, economic and perhaps physical insecurity, paucity of economic 
opportunity, and poor health status of the population. Rural environmental degradation that can be tied to population growth (in the face of technological and institutional rigidities) has plausibly contributed significantly to existing rural poverty in many countries. In the future, however, demographic influence on rural environments will increasingly be a generalized demand effect on the agricultural sector. Any resulting degradation may or may not accentuate poverty but would more clearly be seen as a failure of governance or institutional design. Finally, population growth impinges on the social order, weakening public administration and impeding the emergence of civil society. The intangible returns from social capital are thereby lowered-returns that are potentially as appreciable a contribution to individual welfare and a defense against poverty as direct government services.

\section{LOCAL SCENARIOS OF IMPOVERISHMENT}

The discussion in the preceding section points strongly to population growth contributing to poverty in many situations, either through direct distributional changes in the economy or through routes that involve changes in environmental conditions and social institutions. In each case, no blanket conclusions can be drawn, since outcomes depend on the detailed specification of the setting. There are no automatic linkages, only contingent ones. However, we can appreciably buttress the overall argument by examining the sorts of circumstances that generate population-poverty relationships at the local level.

Micro-level theories of demographic change are essentially formalizations or elaborations of benefit-cost calculations by individuals or families. The best known examples are the works of Becker (1991) and Caldwell 
(1978) on fertility and Harris and Todaro (1970) on migration. Fertility decisions adjust to changes in the perceived costs and benefits of children-with "costs" covering also opportunity and birth control costs. The "perceived" qualification allows for a disjunction between subjective and objective situations. (Although these models are sometimes thought to define a reality in which family planning programs have no role, both knowledge and acceptability of modern birth control methods can clearly be treated within them.) Migration decisions are more simply reducible to a mainly economic calculus, though with a sometimes ill-defined distinction between purely individualistic decisionmaking and the family acting as a miniature corporate entity seeking regional diversification. Child mortality has much less behavioral content, but such a component may still be present: for example, child mortality is influenced by the nature of "health-seeking behavior" on the part of parents and perhaps by intrahousehold allocation decisions.

Understanding the family economy and its demographic responses to changed circumstances and opportunities does not in itself shed much light on population-poverty relationships. The prices and other incentives that determine the costs and benefits of demographic behavior are set by economic forces, social organization, and cultural patterns that an individual family neither controls nor much influences. We thus need to set the family within its material and social environment, and explore the dynamics of this somewhat larger system. The aim is to identify the kinds of organizational patterns that tend to connect population growth and poverty.

\section{Intrafamily transmission of poverty}

A familiar explanation for continued high fertility under difficult economic conditions is that parents in fact stand to benefit from having many 
children. The simple arithmetic that each additional child dilutes family income (which was the main fact driving the Coale-Hoover model, for long the chief rationale for birth control programs) is countered by the subsequent contribution that children make. Children may contribute to family income and to the care of younger siblings from a relatively early age, perhaps at some cost to their own economic prospects; and they may have an asset- and insurance-role for the family — bringing in dowry or bridewealth, establishing kinship links through marriage, and providing support and protection to parents in old age. In the terms used by Caldwell (1978), the net "wealth flows" in the family go from children to parents. The picture conveyed is one of patriarchal wellbeing supported by the economic transfers generated by high fertility, benefiting the family as a whole-albeit unevenly across its members. (Admittedly, solid empirical support for such transfers as a general picture has proven elusive, and there are emerging strands of counterargument-see Lee 1997, and for a critique rooted in evolutionary theory, H. Kaplan 1994.)

Against this traditional if somewhat stylized hypothetical pattern, we can contrast the modern expectation that children of large families would be significantly disadvantaged, particularly in terms of educational investments. Such an effect was seen in the classic work of Blau and Duncan (1967) on occupational mobility in the United States and in results of the subsequent Occupational Change in a Generation study (see Blake 1989). Yet surprisingly, recent research on poor countries is inconclusive. Lloyd's (1994) examination of the evidence finds only a small negative effect - though the average disguises substantial selective disadvantage to some siblings, particularly females. Kelley (1996: 110) concludes from an exhaustive review of quantitative studies that "evidence on the impact of family size on educa- 
tional outcomes is mixed, showing no convincingly consistent and strong impact, one way or the other." Of course, at least at the primary level, direct schooling costs are to some degree socialized in most countries, so sib-size effects would be lessened. As development proceeds, other educational costs would come to dominate and any residual economic advantages of family size would diminish.

Notwithstanding this overall ambiguity, there are particular circumstances in which the costs of a family's high fertility clearly fall on the children. This is the case where high fertility is associated with an early start to childbearing and close birth spacing, or with "unwanted" births. Poor families are likely to be especially susceptible in these respects, through initially lower education, less access to health care, and often less effective birth control. Children's health as well as their education may suffer: for example, parental malnutrition can lead to low-birthweight children and greater risk of stunted development. The likely outcome is to reproduce poverty in the next generation.

Oberai (1993: ch. 6) cites various studies that find high fertility in poor urban families - two or more sons - to be in part a strategy aimed at combating poverty by enhancing economic security, leading to the familiar vicious circle: "low incomes ensure poor education, nutrition and health, which in turn lead to low productivity and low incomes" (p. 191). Efforts to achieve low fertility as a path to economic mobility - as argued, for example, by those who perceive "poverty-induced" fertility declines (see A.M. Basu 1986) — are consistent with this story.

At least as important as formal education in the intergenerational transmission of poverty are the intangible qualities of childraising. The dysgenic 
fears that Darwinism had given rise to were found to be groundless, but not the inheritance of disadvantage through the economic and cultural spheres. Thomas Sowell (1983: 255) has stressed the effect of disadvantage here, in contrast to family surroundings "where the values and patterns of life were a human capital that made economic success more readily attainable." As fertility comes to acquire an inverse gradient by income, the proportion of children raised in conditions of disadvantage rises substantially.

\section{"Tragedy of the commons"}

Garrett Hardin's famous article (1968) gives a stylized picture of population-induced impoverishment through overexploitation of common-property resources. His reference is to pre-enclosure rural Britain, describing a situation in which each new person in a rural community supposedly added a further claim to use of common grazing lands. Beyond some limit in livestock numbers the productivity of the commons would decline, perhaps drastically. Implicitly, the community is taken as composed of members with more or less uniform power, unable or unwilling to act concertedly to impose a management regime to resolve the predicament or to countenance its imposition by unilateral action. The situation is modeled by an n-person prisoner's dilemma, in which each player has an immediate incentive to pursue autonomously self-interested behavior unless a binding agreement to act in the common interest can be reached. Of course if such an agreement can be reached, the outcome is superior for all. Dasgupta and Mäler (1994: 2324) note that there is no necessity that agreement has to entail centralized supervention: decentralized participatory arrangements can be found and would often be preferred. 
Hardin's aim, like that of many subsequent writers on the case, is to illuminate processes of ecological degradation in rural poor-country situations. The common-property resources in question are usually assumed to be open-access forests (as sources of fuelwood and leaf fodder) and local aquifers (for well water). For the dry regions of India, Jodha $(1985,1990)$ lists community pastures, community forests, waste lands, common dumping and threshing grounds, watershed drainages, village ponds, and rivers. With overuse, the productivity of these resources declines, with immediate and disproportionate impact on the poor. The population connection is evident. From an early age children can undertake such essential family tasks as gathering fuel, carrying water, or caring for livestock. But the population growth thereby sustained further worsens the environment's capacity to supply fuel, water, and pasture - thus maintaining or even raising the value of children to parents. Dasgupta's (1993) treatise, An Inquiry into Well-Being and Destitution, discusses the situation in detail, and formalizes the underlying theory.

An urban parallel can be drawn to the Hardin case, identifying a similar kind of prisoner's dilemma. The urban analogue of common-property resources in rural communities is the condition of physical security and comparative social stability that provides the setting for the informal labor market and allows predictability in patterns of social relations. These background conditions in poor urban areas are as much subject to "degradation" as the rural environment.

The circumstances in which population growth does actually lead to impoverishment through these kind of mechanisms are those where cultural or institutional factors impede collective or unilateral action at the local level to limit degradation. Privatization of the resource (alienation or enclosure) 
and cooperative or state management of it are among the options that can halt the decline, an outcome produced by proper alignment of the various economic and political interests in play. Unfortunately, one route for preventing overexploitation is through simple exclusion of some category of claimants. Poverty for all, Hardin-style, may be avoided but not for the excluded group. Clearly critical for a poverty-alleviating outcome is a remedy that also protects against adverse distributional effects. Finally, for longerrun viability, the incentives that are set up should be such as to maintain or increase per capita returns - by raising production or limiting further population growth.

\section{Low-level social equilibria}

The preceding case falls squarely within a rational microeconomic calculus. Theorists within this tradition tend to dismiss the notion that apparently improvident or dysfunctional behavior might be explicable in terms of "tradition" or "culture." But as the understanding of how institutions emerge has grown, so has a new appreciation of customary behavior.

Dasgupta (1993: 351) describes how enmeshed custom can create a social equilibrium that gives rise to significant externalities:

In many societies, there are practices encouraging high fertility rates which no household desires unilaterally to break. . . [S]o long as all others follow the practice and aim at large family sizes, no household on its own will wish to deviate from the practice; however, if all other households were to restrict their 
fertility rates, each would desire to restrict its own fertility rate as well. Thus, there can be multiple social equilibria, each sustained by its own bootstraps, so to speak, and a society can get stuck in one which, while it may have had a collective rationale in the past, does not have one any more.

This picture, novel as it may be to modern economists, is close to the perception of classical theorists like Malthus and Mill who saw education as the input that could shake a society out of a poverty equilibrium. It recognizes that values and preference sets are not fixed as assumed in most welfare theory but are determined in the course of socialization and acculturation and are modified by experience and opportunity, all processes that are not independent of societal design.

A different kind of poverty equilibrium is vividly portrayed in the analysis of social development by Robert D. Putnam (1993). Putnam describes an n-person prisoner's dilemma over whether or not to put trust in civic institutions. Expectations of economic progress take for granted a social infrastructure based on some measure of trust - for instance, belief in security of contract and in a degree of legal and administrative impartiality. This amounts to a cooperative solution to the dilemma under which both the economy and social capital can grow. But there is also a stable equilibrium of shared distrust, with minimal social capital beyond the family and kin-group and a self-reinforcing pattern of exploitative behavior that produces a meager economic performance.

A social equilibrium would seem to bear some resemblance to the problematic idea of a class culture, and a low-level social equilibrium to that of a 
"culture of poverty." These concepts have fallen into disuse in research, though they clearly persist in popular understanding of, for example, the urban underclass. Traits making up a culture of poverty included authoritarianism, present-time orientation, and fatalism (O. Lewis 1961), with the all-too-easy implication that they formed a coherent belief system resistant to change. Critics of the concept preferred to see the behavior of low-income people as a pragmatic response to deprivation and stress-as "responsive to the conditions of life rather than to cultural guidelines" (Rodman 1968: 335). Policy is thereby given something tangible to work with. "Traps" and similar equilibrium concepts are always contingent on a modeling structure that, even if initially valid, may be rendered obsolete by trends in the real world.

\section{Unilateral transfers: offloading costs onto the weak}

The two preceding scenarios have dealt with poverty arising from or maintained by the presence of reciprocal negative externalities-situations in which each family transfers some of its fertility costs onto the rest of society and reciprocally bears part of others' costs itself, with the diffusion of costs making remedial action difficult. Transfers of costs need not of course be reciprocal. In the intrafamily case with which we started, children could be disadvantaged by having many siblings: that is, there could be unilateral transfers onto children within a household. There are other kinds of unilateral transfers, however, some of which are probably more important in influencing poverty outcomes.

Members of one community can worsen conditions in another through environmental spillovers—-for instance, through poor agricultural practices 
whose local effects can be avoided but that are felt elsewhere through, say, pollution or flooding. They can also do so by exertion of political power or direct force to gain an economic advantage, for example through alienation of what previously had been common-property resources. In a weaker sense, labor migration also represents a transfer of costs of population growth, in this case onto participants in the recipient area's labor market. (Employers in the recipient area may of course stand to benefit from greater labor market competition, complicating the cost calculation.) Rural-urban migration can sometimes be viewed in this way, as in the Brazilian case noted earlier. "Communities" here would usually refer to territorially defined entities like villages or regions; quite analogous arguments, although for a possibly different range of transfers, can apply to groups defined by economic status, such as class or caste groups. Indigenous minorities are often the involuntary recipients of offloaded costs associated with population growth elsewhere. In some circumstances, women may be too.

Unilateral transfers with implications for poverty outcomes can also be intertemporal. The next generation in a society "inherits" from the present generation its physical and human capital, natural resources, and environmental amenity. Under rapid population growth, population numbers would often double in a generation, imposing a major dilution effect on this inheritance. It is the case of intrafamily transfers writ large. (There are many conceptual and even ethical problems in delineating this case. Dasgupta [1993: ch. 13] gives a brief treatment of them.)

The common feature of unilateral transfers is the inability of those on whom the costs are imposed to organize effectively to protect their interests. This may reflect the structural weakness of their position in the larger soci- 
ety, geographical remoteness, or, in the intertemporal case, inherent obstacles to intergenerational contracting.

\section{Poverty and the "threat economy"}

The "threat economy" is a term of Kenneth Boulding's, applied to the economy of arms races. At the micro level, however, resources similarly have to be allocated to protection-against social predation. As the earlier discussion of political stability suggested, demographic pressures are one among various factors that might be expected to harm the social fabric. An anecdotal account of such harm in various countries of West Africa and West and Central Asia, arguing for at least partial demographic causation, is given by R.D. Kaplan (1996). The erosion of social capital is not easily reversed: indeed, it is likely to result in forms of social organization that are antithetical to economic and political development. Such forms-warlordism, for instance-might offer protection for some but at the expense of predation on others; plausibly they would entrench both pre-transition demographic outcomes and widespread poverty.

\section{LOCATING POVERTY BY SOCIO-DEMOGRAPHIC CATEGORIES}

Stories about the poverty effects of population change tend to focus on processes rather than outcomes; they pay little attention to who the poor are. A different and more conventionally demographic approach to the subject would be organized around the socio-demographic categories in which the poor are likely to be concentrated. A brief sketch will suffice here, since most of the relevant materials have already been introduced. 


\section{Poverty and women}

Women are more often in poverty than men. Detailed statistical materials, for example from the 1995 Human Development Report, support the proposition. A.M. Basu (1994: 18) finds conclusive evidence of "a widespread disproportionate impact of poverty on women." Kabeer (1996: 19) remarks that women "are less able than men to translate labor into income, income into choice and choice into personal well-being."

Two fairly distinct phenomena are implicated. One relates to the status of women who are widowed, divorced, or separated, and to the level of autonomy and economic opportunity open to single women; the other, to the position of women within marriage and within the household. The first of these combines effects of gender with those of social isolation and old-age dependency (sex differences in average age at marriage and in adult mortality mean that the single elderly are predominantly women). Poverty can be linked to gender-differentiated aspects of law and social practice in areas of property, inheritance, and occupational choice, and to the precarious economics of single-person or single-parent households. Children, and sons especially, may be an important economic resource for widows-as stressed, for instance, by Cain (1978) — but this fertility connection would plausibly diminish as alternative sources of security emerge in the course of economic development.

The second phenomenon is more complex. Its documentation hinges on fairly intricate research on intrahousehold allocation and on assumptions about nutritional needs, culture, and equity (see Haddad et al. 1997). South Asia has been the locus of much of this research. Harriss (1990) presents a 
lengthy and thorough survey of the evidence and explanations for intrahousehold food allocation in that region. External conditions may give rise to a material rationale for discrimination against women and girls under conditions of scarcity, in terms of a household's survival strategy in confronting a labor market structured in favor of males and in terms of differences in expected future costs and returns to childraising between girls and boys. There is also a cultural level of explanation, involving "observance of the moral order governing distribution" of food (p. 409)—an order that seemingly is poorly informed of nutritional basics. Allocative outcomes are conditioned by patriarchal beliefs and social relations, but ones that exist as much outside the household as within it. Harriss lists the various elaborate proposals for "more or less highly targeted therapeutic interventions to remedy nutritional discrimination" (p. 411) but is quite skeptical of their worth.

\section{Poverty and children}

Poverty might be expected to vary with the number of household members economically active. Visaria (1980: 202-203) presents evidence of this from a series of World Bank living standards surveys in Asian countries. Ranking households by per capita expenditure, the age dependency ratio (of persons outside the age-range 15-59 to persons within it) "varies inversely with decile, virtually monotonically." The ratio for the top decile is a half or a third that for the bottom decile. Most of this effect is variation in child dependency.

The distinction of two- versus one-earner families has become salient in many industrialized societies and results in substantial differences in child 
poverty rates. The family-structure contrast between two-parent and femaleheaded families largely reflects this difference in earning capacity. For the United States, child poverty rates as of 1988 were 10 percent for two-parent families, 54 percent for female-headed families (Galston 1996: 276).

Poverty that is linked to high child dependency derives from two main sources: the income-diluting effect of a larger number of dependent consumers and the behavioral effect of socioeconomic status on fertility. (There may of course be other contributing factors as well.) The first of these components would presumably diminish as children become economically active, but it is not less real for being transitory. It may also have long-run consequential effects by curtailing children's education in the interests of raising family income.

To the extent that poorer families have more children, the proportion of children in poverty will be higher than the proportion of families or of adults in poverty. The usual pattern of fertility decline can exacerbate this effect. Jones and Potter (1978: 22) cited the case of Colombia over a period during which the annual growth rate decreased from 3.1 percent to 2.2 percent: "when the birth rate was above 45 in 1964 about half of each cohort was born into the poorest 50 percent of all households. In 1973, when the birth rate had declined to the low thirties, the share of children born into these households increased to about two-thirds."

In democratic welfare states, fertility decline can also worsen child poverty through the political arena. The proportionately more numerous elderly brought about by population aging acquire greater influence over social policy, particularly as it affects the direction and scale of transfer payments. Payments that benefit the older age groups may become politically unassail- 
able, so that any constraints on the overall scale of budgetary transfers are disproportionately felt by other potential claimants-notably, poor families with dependent children. This is the generational politics argument developed in Preston (1984).

\section{Poverty and the aged or disabled}

In most developing societies welfare-state institutions are in their infancy. In particular, broad-based provisions for old-age security have yet to emerge. Only a minority of employees, chiefly in the public sector, are covered by pension schemes. Instead, the state takes it for granted that old-age security should be the responsibility of families. It may even enshrine this obligation in law, as in the 1980 marriage law of China, seeking to insist on familial responsibility against the forces tending to erode it. But such efforts, whether hortatory or regulatory, seem bound to fail—if only because, with declining fertility, networks of kin become thinner (see Lutz 1989) and the burden of upward transfers per working member of the family increases. Moreover, there would remain a need to provide for the childless elderly and for those whose families for whatever reason default on this obligation.

Many elderly would of course expect to support themselves from accumulated assets. Some part of a family's support of its aged members is in fact a graduated process of asset transfer. Poverty among the old is concentrated among those with few or no assets: to a first approximation, it is a continuation of poverty among the population in general. The additional components are contributed by ill-health and disability, by increased vulnerability to predation, and by whatever structural disadvantage there may be in 
the society's treatment of widowhood. To the extent that low fertility and consequent population aging are occurring in contemporary societies at lower economic levels than experienced historically, problems of old-age support and of old-age poverty are the greater.

Ill-health and disability are causes of poverty that are not only felt in old age. Disability in the sense of productivity impairment is not a welldefined concept: the degree of impairment may depend on numerous technological, societal, and policy factors and be specific to occupation. Certain disease regimes, however, almost guarantee poverty-e.g. river blindness (see Evans 1989).

\section{Poverty and refugees}

Most refugees are in poverty virtually by definition, stripped of assets and income. The formal specification of a refugee, entailing international displacement and a well-founded fear of persecution, covers only a fraction of those in effectively similar situations. Indeed, political activism would often connote persons with significant human capital who, in new circumstances, could rapidly climb out of poverty. Persons suffering internal displacement within a country are seldom better off and may be in appreciably worse situations than those afforded UNHCR recognition across the border. The earlier discussions of the social order and the threat economy considered refugee-creating processes that were at least partially associated with population growth.

A conceptually and statistically more elusive category is what have become known as environmental refugees: persons displaced by changes in the physical environment rather than by military force or civil conflict. Some 
estimates put these numbers at many millions. There are evidently clear-cut cases of forced displacement as a consequence of rapid deterioration of the resource base or the flooding of agricultural land by newly dammed rivers; but aside from such cases there is no sharp dividing line between those migrating to avoid a drop in living standards caused by environmental degradation and those seeking an improved standard of living elsewhere.

\section{Population Policy and Poverty Alleviation}

Poverty and fertility are not in themselves policy instruments, in the sense of one of them being able to be modified so as to affect the other. Lessening poverty will not necessarily bring down high fertility (for inequality in general, the difficulties are discussed in the exchange between Boulier 1982 and Repetto 1982). Nor will a fertility decline in itself necessarily help to alleviate poverty (see, for example, Rodgers et al. 1989). But dismissing policy prospects at that broad level does not dispose of the matter. The policy domains within which population and poverty are open to intentional influence intersect, allowing for measures that impinge on both areas-with possibilities for generating "virtuous circles" and "win-win" outcomes benefiting both. Because population-poverty relationships are institutionally contingent, such measures have to be tailored to the specific situation. However, a few more general observations can be made.

\section{Programmatic policies: education, health, family planning}

Both poverty and the components of population growth (fertility especially) are what might be described as devolved phenomena. They refer to 
individual- or family-level characteristics and behaviors. They are reachable by government only through broadscale extension services or by policies that yield welfare gains across the income distribution and across gender lines - or, we need to add, by the elaborate measures of administrative control entailed in detailed "targeting" of policy. This devolution makes for a degree of consonance in policies directed at limiting population growth and those concerned with poverty alleviation.

Improvements in education and health are closely linked to demographic modernization. Caldwell's (1986) analysis of low-mortality "outliers" among poor countries argues the mortality case; the fertility relationship is attested by numerous quantitative studies. Significantly, education and health are precisely the sectors where government action, properly designed, can also most readily serve redistributive ends. Sectoral budgets themselves may not mean much: universities and high-technology hospitals can consume large amounts of resources but reach few in the population and raise rather than reduce economic inequality. Primary and secondary schooling and primary health care are the relevant extension services, contributing directly to wellbeing as well as to earning capacity. Achievement of high primary- and secondary-school enrollment rates necessitates near universality of service provision; and to be effective, primary health care must similarly be widely available at the local level and acceptable in quality.

The administrative and financial structures of these sectors are also relevant to their impact. Accountability to clients may be a surer means of achieving service quality than bureaucratic supervision. Such accountability is more likely to be found where the financing of services includes a significant locally raised component-through local taxes and perhaps user 
fees (provided access is not thereby skewed). De facto, such devolved financing is often the case, but without insistence on accountability.

There is some evidence at the macro level that rapid population growth is associated with poorer budgetary provision for education and health (see G.W. Jones 1990). This is a disputed area, however. Budgets reflect government priorities, and social services often do not rank very high. Conditionality stipulations-particularly those associated with structural adjustment programs - are sometimes blamed for this ranking, but the case tends to be weak. Conditionality may even work in the opposite direction: the 1990 World Development Report argued that aid allocations "should be based on a demonstrated commitment to the goal of reducing poverty" (p. 141). A more significant influence on budgeting is likely to be the political and lobbying forces surrounding the process at the top level—as implied in Kaushik Basu's (1990: 370) trenchant comment that "South Asian economies are Finance Minister neutral."

Family planning programs, at least in their pre-Cairo formulation, are in essence just another kind of extension service. The client-demand may be softer than in the case of health and education, but the administrative requirements qua program are not radically different. Their welfare effect on the poor is less easily identified, however. Most of this review has assumed that fertility outcomes reflect the interests of parents or families; but some part of fertility reflects ineffectiveness of available birth control methods. Access to safe and effective birth control is likely to be strongly associated with parents' socioeconomic status, in particular with education and income. Thus "unwanted" fertility is disproportionately found among the poor. Family planning programs, aimed principally at those who lack access to private 
sources of modern contraception, thus have an important distributional dimension: the services they provide, in addition to any social gain that may come from reduced fertility, offer a private gain mostly to the poor. (This, of course, assumes that the services are fully voluntary; if they are not, the social gain would be set against a private cost.)

Family planning post-Cairo, with its aim of cutting back any explicit demographic intentions and focusing instead on improving the reproductive health of women and their access to high-quality services, is still closer to an extension service-conceptually not distinct from other more or less specialized components of the health program. The changed orientation may attenuate the program's redistributive effect: as service quality is raised, the program may well find itself catering to a more middle-class clientele than before.

\section{Target groups versus rising tide}

If women are overrepresented among the poor, measures to lessen poverty, many would argue, are reasonably directed disproportionately toward women. Analogous propositions would apply to the various other population categories where poverty rates are high: children, the elderly, ethnic minorities, inhabitants of particular backward regions, and so on-depending on the specific circumstances in the society. As the numbers in such categories start adding up to appreciable fractions of the whole population, the benefits proffered come to include a large consumer surplus and become unaffordable. If the poor within each target group can be identified, however, the group designation becomes redundant.

Consider policies that might lessen female poverty. The structural causes of poverty, such as women's second-class status in inheritance and property 
rights in some societies, may be resistant to change except over the long run; indirect means of enhancing female earning power and autonomy may have more prospects of near-term effect. Ensuring equal access to education is clearly important, as is ensuring that health and family planning programs cater to the needs of poor families. To the extent that net fertility and childraising costs fall more heavily on women than men, the economic benefit of these programs also goes disproportionately to women. Design changes in certain other government extension activities can make them more oriented to women-for example, in credit systems or in the targeting of agricultural extension services in situations where food crops are predominantly cultivated by women.

What of the demographic effect of these measures? There is a general belief that policies to improve women's autonomy — particularly in their access to education and health services-are effective in reducing both fertility and mortality (A.M. Basu 1992: 241). Evidence on the mortality side seems incontestable; on fertility, the case is somewhat blurred by the prominent instances of fertility decline under much less than autonomous circumstances.

Attention to gender equity resounds in international declarations and covenants; it has become one of the routine emphases of the policy recommendations of international agencies. Increasingly, it is translated into practice by national governments. For example, Knodel and Jones (1996) find that gender inequality in access to secondary education is fast diminishing in much of the developing world. However, these authors caution that poverty considerations may get neglected along the way: "in most developing countries a specific gender focus [in education] is misplaced, or should be given only secondary priority relative to reducing socioeconomic inequality for both sexes" (p. 698). 
Programmatic efforts and the targeting that typically accompanies them entail close government involvement. Less statist development strategies would rely primarily on aggregate growth in the economy to raise base-level wages and absorb unskilled labor, and to effect changes in demand (for education and for health and family planning services) that in turn elicit privatesector responses. The now-universal early development strategy of encouragement of labor-intensive manufactured exports is directed at overall economic growth rather than specifically at poverty reduction, but it was the underpinning of the "growth with equity" performance of the East Asian economies - and promises significant poverty alleviation elsewhere. The large ideological gap between the programmatic and growth-promotion approaches is narrowed in practice by the common fact of governments falling well short of declared program intent, together with de facto part-privatization of their operations, and by the substantial if behind-the-scenes management role governments have taken in some of the most successful cases of economic growth.

\section{Institutional renovation}

Poverty traps of the kind discussed earlier in this review are cases where the patterns of economic, social, or political organization create the wrong incentives for individuals or groups, resulting in economic decline, environmental degradation, or decay of social capital. There are no general rules to apply in these cases - even the economist's dictum of internalizing the externalities is not always appropriate. Each case warrants separate analysis. Finding a way out is often not difficult in theory but may be very difficult in practice. 
One kind of policy intervention is aimed at dealing with the environment of risk faced by the poor. Mink (1993) emphasizes security of tenure for farmers and urban squatters and collective rights in the case of commonproperty resources. This helps to lengthen time horizons and lessen the "mining" of resources. Institutional programs to cope with crisis events such as crop failure, so as to prevent distress sale of land, are also called for-such as formal or informal crop insurance, or supplementary public works schemes like that of Maharashtra (Cain 1981).

For those suffering from unilateral cost transfers and not able to organize to protect their interests, the options are few. Government may be persuaded to exercise a supervening authority in halting the transfers or granting some compensation; more often, little is done and perhaps little can be done. If overall poverty is on a downward trend, there is rarely any insistence on ensuring that the growth path obeys strict principles of Pareto improvement.

The most intractable setting for policy is that of the failed state, where much of the physical infrastructure has been damaged or destroyed and minimal social capital remains. While there is ample reason for pessimism that any development progress is possible in the worst cases, there are instances of countries that have undergone a prolonged deterioration in civil order but are again moving up. Ghana and Uganda are cases in point. People retain institutional memories, of course, but the scope for institutional redesign in such circumstances is potentially large.

\section{Poverty, authoritarianism, and democracy}

A number of East and Southeast Asian countries have witnessed both a remarkable performance in economic growth over several decades (though 
lately encountering some serious problems) and at the same time major reductions in both poverty and fertility. The achievement is widely applauded, but variously interpreted. Birdsall et al. (1995) emphasize measures that raised productivity of the poor: promotion of a dynamic agricultural sector and labordemanding, export-oriented manufacturing; and rapid expansion of basic education. One of the "virtuous circles" they identify has the growing numbers of educated workers eroding the scarcity rents of the more educated, reinforcing low inequality and further increasing the labor demand. Equally virtuous is the economic gain from the reduction in child dependency following from the fertility decline that the economic expansion promoted.

Indonesia's experience from the 1970s to the mid-1990s in most ways typifies this policy model (see Hill 1996). Between 1976 and 1993 the poverty rate in Indonesia declined from 40 percent to 13 percent, and the numbers in poverty halved (to 25 million). Fertility fell substantially too, from a total fertility rate of above 5 to around 3. By the mid-1970s, the reformist government that had come to power in 1967 had stabilized the economy and embarked on rehabilitation of the badly run-down physical infrastructure. It had moved strongly to support the food crop sector, through promotion of green revolution technologies and subsidized inputs. It had also initiated a vigorous family planning program that mobilized the newly energized civil administration in support of its extension services. Fortuitously, government resources were boosted by the revenues from higher oil prices in the 1970s, a significant proportion of which were channeled into local infrastructure and development projects and improvements in the education and health systems. Subsequently, in the 1980s, Indonesia began to achieve strong growth of labor-intensive manufactured exports-along the lines earlier pioneered by Japan, South Korea, and Taiwan. 
These factors in combination fairly readily explain both the reduction in poverty and the demographic change. (For poverty reduction it helped, of course, that Indonesia did not start with large concentrations of private wealth in its agricultural sector - unlike, say, the Philippines.) Job creation, higher agricultural productivity, and improved health and education enhanced earnings power at the grass-roots level. These same trends, together with changed expectations about the economic future and recognition of the need for (and costs of) education, lowered family size goals. An effective distribution system for modern contraceptives met the consequent demand for birth control-though administrative pressures were used in some measure to supplement it.

The strong performance that Indonesia showed over these decades on both poverty alleviation and fertility decline was mutually reinforcing. In the new conditions "quality" of children mattered more than "quantity." Greater grass-roots opportunities raised the demand for and use of birth control at the lower end of the income distribution; and reduction in fertility among the poor helped their economic circumstances. The severe regional economic crisis encountered in 1997 may for a time reverse the decline in poverty but the demographic gains are unlikely to be affected.

A contentious aspect of the East Asian experience is the restrictions on political freedom found in much of the region. This issue lies mainly outside the scope of the present review, though it bears on the evaluation of the East Asian case-particularly in comparison to South Asia. It requires mention here, however, because some major writers on population and poverty like Amartya Sen and Partha Dasgupta regard it as highly relevant to the definition of wellbeing, and because the case is sometimes made that it is empirically tied to the favorable demographic and development outcomes. 
Whether poverty ought to incorporate a political dimension is somewhat questionable. It may be to overload the concept. As noted earlier, the elaborate composite indexes that proliferate in the successive Human Development Reports arguably have this problem in attempting to bridge measures of income and health. An index of political freedom, a potential end to a still longer bridge, appeared in an early Human Development Report, but soon disappeared under objections from low-scoring states. International comparison might be as well served by a series of sectorally confined measures.

A political dimension frequently intrudes in population policy-not in family planning rhetoric, where the fully voluntaristic model prevails, but in practice (see McNicoll 1997). Birth control programs, like many other government activities, draw on the administrative power of the state. An authoritarian state tends to run authoritarian programs, whether in fertility or in the kinds of extension services that have contributed to a reduction in poverty as narrowly construed. At least early in the course of development, program effectiveness, it seems, does not imply or require democracy. Once the development process has lifted a society significantly above subsistence levels, however, the case for taking seriously this further dimension of wellbeing, and the voice for service quality that it makes room for, rapidly gains strength.

\section{CONCLUSION}

The "restatement" of the population-poverty relationship set out in this essay began with the agnostic conclusions of cross-country multivariate analysis. These are part of a perennially unfinished research agenda that seemingly extends across most of the subject of the consequences of population growth at the aggregate level. Closure is unlikely even if the latest positive 
associations of fertility decline with economic growth are borne out. The problem here, I believe, is one of flawed expectations: what should be sought is not some final measure of statistical association such as a tight regression equation, but a collation of insights about how the world works. In the population-poverty case, this means insights that take account of the environmentally and institutionally configured setting of the relationship at a variety of levels-local, sectoral, and national. Such insights can emerge from elaborate case studies, but also from ad hoc comparisons and stylized models. While there is always an appetite for new data, the more immediate need is to pull together and interpret existing analyses and findings. The materials referred to above are a sampling of these.

The organizing framework I have used distinguished "direct" influences of population growth on economic distribution and hence poverty outcomes from influences working through environmental change and change in the social order and governance. In turn, poverty outcomes could be analyzed in terms of the economic transfers generating them-such transfers typically enjoying at least local stability, with the winners able to sustain the arrangement or the losers unable to disrupt it.

Equilibrium traps, of course, can be escaped from. Simple geographic mobility offers one route: the option of "exit." Organizational change or other kinds of local institutional reform can also offer escapes-for example, by improving production incentives or by mobilizing collective efforts to enforce distributional changes (typically through demands on government). And programmatic interventions, either intentionally or sometimes as an almost incidental byproduct of their main purpose, transform local perceptions and realities in ways that create new avenues of economic mobility and 
associated demographic behavior. These options make up most of the usual repertoire of policy measures bearing on population and poverty.

Such a policy set encounters dissent from two directions. On one side are those who are opposed to any linking of demographic concerns with poverty alleviation. They claim to see the ancient debates over the Poor Laws and over the harsh Malthusian response continuing in new guise, the poor in effect being blamed for their fertility as well as their poverty. A residue of the stance that population control was a counter-revolutionary measure may have lain behind the downplaying of demography in the Cairo Programme of Action - in which a welter of policy recommendations contained a radical program of social reform but dealt hardly at all with fertility regulation.

Dissenters on the other side, in my view with a more substantial case, hold simply that these intervention efforts may be sideline activities largely unconnected to the main game of creating a modern economy and the prosperity it affords - with one byproduct being a modern demographic regime. (Other byproducts, it can fairly be hoped, would be improved environmental quality and a democratic polity.) Most writers on the policy dimensions of poverty and population are concerned with the incontestable direct effects of intervention programs - their immediate, measurable benefits to clientsand with possible improvements in program design, matters they would see as central to the policymaking enterprise. To them, a single-minded emphasis on economic growth would be neglecting some of the most important elements of public policy affecting human welfare. But perhaps they are merely tinkering. India's development performance was assessed in the Times Literary Supplement by two of its most distinguished economists on the fiftieth anniversary of independence. Amartya Sen wrote of the country's achievements in health, democratic government, and economic advance, al- 
beit slow. Jagdish Bhagwati (1997) described India's entire apparatus of economic administration as "this remarkable machine for producing backwardness."

\section{References}

Ahlburg, Dennis A. 1996. "Population growth and poverty," in Dennis A. Ahlburg et al. (eds.), The Impact of Population Growth on Well-being in Developing Countries. New York: Springer-Verlag.

Anand, Sudhir and Amartya K. Sen. 1997. "Concepts of human development and poverty: a multidimensional perspective," Human Development Report 1997 background paper.

Bardhan, Pranab (ed.). 1989. Conversations between Economists and Anthropologists: Methodological Issues in Measuring Economic Change in Rural India. Delhi: Oxford University Press.

Basu, Alaka Malwade. 1986. "Birth control by assetless workers in Kerala: the possibility of a poverty-induced fertility transition," Development and Change 17: 265-282.

Basu, Alaka Malwade. 1992. Culture, the Status of Women, and Demographic Behaviour. Oxford: Clarendon Press.

Basu, Alaka Malwade. 1994. "Women, poverty and demographic change: some possible interrelationships over space and time," paper presented at the IUSSP Seminar on Women, Poverty and Demographic Change, Oaxaca, Mexico, October 1994.

Basu, Kaushik. 1990. "The elimination of endemic poverty in South Asia: some policy options," in Drèze and Sen (1990), Vol. 3.

Baulch, Bob. 1996. "The new poverty agenda: a disputed consensus," IDS Bulletin 27, no. 1: 1-9.

Becker, Gary S. 1991. A Treatise on the Family. Enlarged edition. Cambridge: Harvard University Press. 
Becker, Gary S., Kevin M. Murphy, and Robert Tamura. 1990. "Human capital, fertility, and economic growth," Journal of Political Economy 98: S12-S37.

Bell, Clive. 1987. "Development economics," in John Eatwell et al. (eds.), The New Palgrave: A Dictionary of Economics. London: Macmillan.

Bhagwati, Jagdish. 1997. "A machine for going backwards," Times Literary Supplement, August 8, pp. 11-12.

Birdsall, Nancy, David Ross, and Richard Sabot. 1995. "Inequality and growth reconsidered: lessons from East Asia," World Bank Economic Review 9: 477-508.

Blake, Judith. 1989. Family Size and Achievement. Berkeley: University of California Press.

Blau, Peter M. and Otis Dudley Duncan. 1967. The American Occupational Structure. New York: Wiley.

Boulier, Bryan L. 1982. "Income redistribution and fertility decline: a skeptical view," Population and Development Review 8 (Supplement): 159-173.

Brockerhoff, Martin and Ellen Brennan. 1998. "The poverty of cities in developing regions," Population and Development Review 24 (forthcoming).

Cain, Mead. 1978. "The household life cycle and economic mobility in rural Bangladesh," Population and Development Review 4: 421-438.

Cain, Mead. 1981. "Risk and insurance: perspectives on fertility and agrarian change in India and Bangladesh," Population and Development Review 7: 435-474.

Caldwell, John C. 1978. "A theory of fertility: from high plateau to destabilization," Population and Development Review 4: 553-577.

Caldwell, John C. 1986. "Routes to low mortality in poor countries," Рориlation and Development Review 12: 171-220. 
Chen, Shaohua, Gaurav Datt, and Martin Ravallion. 1994. "Is poverty increasing in the developing world?" Review of Income and Wealth 40, no. 4: 359-376.

Dasgupta, Partha. 1993. An Inquiry into Well-Being and Destitution. Oxford: Clarendon Press.

Dasgupta, Partha and Karl-Göran Mäler. 1994. Poverty, Institutions, and the Environmental-Resource Base. Washington, D.C.: World Bank. (World Bank Environment Paper, No. 9.)

De Soto, Hernando. 1989. The Other Path: The Informal Revolution. New York: Harper and Row.

Drèze, Jean and Amartya Sen (eds.). 1990. The Political Economy of Hunger. Oxford: Clarendon Press. 3 vols.

Duncan, Greg J. 1984. Years of Poverty, Years of Plenty: The Changing Economic Fortunes of American Workers and Families. Ann Arbor: Institute for Social Research, University of Michigan.

Eckholm, Erik P. 1976. Losing Ground: Environmental Stress and World Food Prospects. New York: Norton.

Economy, Elizabeth. 1997. Environmental Scarcities, State Capacity, Civil Violence: The Case of China. Cambridge, MA: American Academy of Arts and Sciences.

Evans, Timothy. 1989. "The impact of permanent disability on rural households: river blindness in Guinea," IDS Bulletin 20, no. 2: 41-48.

Fei, John C.H. and Gustav Ranis. 1964. Development of the Labor Surplus Economy: Theory and Policy. Homewood, IL: Irwin.

Galston, William A. 1996. "The reinstitutionalization of marriage: political theory and public policy," in David Popenoe et al. (eds.), Promises to Keep: Decline and Renewal of Marriage in America. Lanham, MD: Rowman and Littlefield. 
Gizewski, Peter and Thomas Homer-Dixon. 1995. Environmental Scarcity and Violent Conflict: The Case of Pakistan. Washington, D.C.: American Association for the Advancement of Science.

Goldstone, Jack A. 1991. Revolution and Rebellion in the Early Modern World. Berkeley: University of California Press.

Goldstone, Jack A. 1997. "Population growth and revolutionary crises," in John Foran (ed.), Theorizing Revolutions: New Approaches from Across the Disciplines. London: Routledge.

Haddad, Lawrence, John Hoddinott, and Harold Alderman (eds.). 1997. Intrahousehold Resource Allocation in Developing Countries: Models, Methods, and Policy. Baltimore: Johns Hopkins University Press.

Hardin, Garrett. 1968. "The tragedy of the commons," Science 162: 12431248.

Harris, John R. and Michael P. Todaro. 1970. "Migration, unemployment and development: a two-sector analysis," American Economic Review 60:126-142.

Harriss, Barbara. 1990. "The intrafamily distribution of hunger in South Asia," in Drèze and Sen (1990), Vol. 1.

Higgins, Matthew and Jeffrey G. Williamson. 1997. "Age structure dynamics in Asia and dependence on foreign capital," Population and Development Review 23: 261-293.

Hill, Hal. 1996. The Indonesian Economy since 1966: Southeast Asia's Emerging Giant. Cambridge: Cambridge University Press.

Homer-Dixon, Thomas F. 1991. "On the threshold: environmental changes as causes of acute conflict," International Security 16, no. 2: 76-116.

Homer-Dixon, Thomas F. 1994. "Environmental scarcities and violent conflict: evidence from cases," International Security 19, no. 1: 5-40. 
Islam, R. (ed.). 1985. Strategies for Alleviating Poverty in Rural Asia. Bangkok: ILO-ARTEP.

Ives, Jack D. and Bruno Messerli. 1989. The Himalayan Dilemma: Reconciling Development and Conservation. New York: Routledge.

Jodha, N.S. 1985. "Population growth and the decline of common property resources in Rajasthan, India," Population and Development Review 11: $247-264$.

Jodha, N.S. 1989. "Social science research on rural change: some gaps," in Bardhan (1989).

Jodha, N.S. 1990. "Depletion of common property resources in India: micro-level evidence," in G. McNicoll and M. Cain (eds.), Rural Development and Population: Institutions and Policy. New York: Oxford University Press.

Johnson, D. Gale. 1994. "Effects of institutions and policies on rural population growth with application to China," Population and Development Review 20: 503-531.

Jones, E.L. 1988. Growth Recurring: Economic Change in World History. New York: Oxford University Press.

Jones, Gavin W. 1990. Population Dynamics and Educational and Health Planning. Geneva: World Employment Programme, International Labour Office.

Jones, Gavin W. and Joseph E. Potter. 1978. "The economic consequences of population change," paper presented at the IRG Workshop on Research Priorities for Population Policy, Colombo, Sri Lanka.

Kabeer, Naila. 1996. "Agency, well-being and inequality: reflections on the gender dimensions of poverty," IDS Bulletin 27, no. 1: 11-21.

Kaplan, Hillard. 1994. "Evolutionary and wealth flows theories of fertility: 
empirical tests and new models," Population and Development Review 20: 753-791.

Kaplan, Robert D. 1996. The Ends of the Earth: A Journey at the Dawn of the 21st Century. New York: Random House.

Kasperson, Jeanne X., Roger E. Kasperson, and B.L. Turner II (eds.). 1995. Regions at Risk: Comparisons of Threatened Environments. Tokyo: United Nations University Press.

Kelley, Allen C. 1996. "Population growth and education," in Dennis A. Ahlburg et al. (eds.), The Impact of Population Growth on Well-being in Developing Countries. New York: Springer-Verlag.

Kelley, Allen C. and Robert M. Schmidt. 1994. Population and Income Change: Recent Evidence. Washington, D.C.: World Bank. (World Bank Discussion Papers, No. 249.)

Kelley, Allen C. and Jeffrey G. Williamson. 1974. Lessons from Japanese Development: An Analytic Economic History. Chicago: University of Chicago Press.

Khan, A.R. and E. Lee (eds.). 1983. Poverty in Rural Asia. Bangkok: ILOARTEP.

Knodel, John and Gavin W. Jones. 1996. "Post-Cairo population policy: does promoting girls' schooling miss the mark?" Population and Development Review 22: 683-702.

Lee, Ronald D. 1997. “A cross-cultural perspective on intergenerational transfers and the economic life-cycle," in A. Mason (ed.), Intergenerational Economic Relations and Demographic Change. New York: Oxford University Press.

Leibenstein, Harvey. 1954. A Theory of Economic-Demographic Development. Princeton: Princeton University Press. 
Lewis, Oscar. 1961. The Children of Sánchez: Autobiography of a Mexican Family. New York: Random House.

Lewis, W.A. 1954. "Economic development with unlimited supplies of labour," Manchester School 22: 139-191.

Lipton, Michael. 1997. "Interactions between poverty and population change, and some linkages to environmental depletion," paper prepared for the UNDP Sustainable Human Development program.

Lloyd, Cynthia B. 1994. "Investing in the next generation: the implications of high fertility at the level of the family," in Robert Cassen et al., Population and Development: Old Debates, New Conclusions. New Brunswick, NJ: Transaction Publishers.

Lloyd, Cynthia B. 1995. "Household structure and poverty: what are the connections?" Working Paper no. 74, Research Division, Population Council, New York.

Lutz, Wolfgang. 1989. Distributional Aspects of Human Fertility. London: Academic Press.

McNamara, Robert S. 1995. "A global population policy to advance human development in the twenty-first century," in Robert J. McNamara, Roger V. Short, and Crispin Tickell, World Population Growth, Natural Resources, and Human Health. Dallas: Cecil and Ida Green Center, University of Texas.

McNicoll, Geoffrey. 1984. "Consequences of rapid population growth: an overview and assessment," Population and Development Review 10: 177-240.

McNicoll, Geoffrey. 1997. "Governance of fertility transition: reflections on the Asian experience," in Gavin W. Jones et al. (eds.), The Continuing Demographic Transition. Oxford: Clarendon Press. 
Merrick, Thomas W. and Elza Berquo. 1983. The Determinants of Brazil's Recent Rapid Decline in Fertility. Washington, D.C.: National Academy Press.

Miller, S.M. 1996. "The great chain of poverty explanations," in Øyen et al. (1996), pp. 569-586.

Mink, Stephen D. 1993. Poverty, Population, and the Environment. Washington, D.C.: World Bank. (Discussion Paper No. 189.)

Morley, Samuel A. 1981. "The effects of changes in the population on several measures of income distribution," American Economic Review 71: 285-294.

Murray, Christopher J.L. and Alan D. Lopez (eds.). 1996. The Global Burden of Disease. N.p.: Harvard School of Public Health.

Nelson, Richard R. 1956. "A theory of the low level equilibrium trap in underdeveloped economies," American Economic Review 46: 894-908.

Oberai, A.S. 1993. Population Growth, Employment and Poverty in ThirdWorld Mega-Cities: Analytical and Policy Issues. New York: St. Martin's Press.

Ooi, Jin Bee. 1988. Depletion of the Forest Resources in the Philippines. Singapore: Institute of Southeast Asian Studies.

Øyen, Else. 1996. "Poverty research rethought," in Øyen et al. (1996), pp. 3-17.

Øyen, Else, S.M. Miller, and Syed Abdus Samad (eds.). 1996. Poverty: A Global Review. Handbook on International Poverty Research. Oslo: Scandinavian University Press.

Percival, Valerie and Thomas Homer-Dixon. 1995. Environmental Scarcity and Violent Conflict: The Case of Rwanda. Washington, D.C.: American Association for the Advancement of Science. 
Portes, Alejandro and Lauren Benton. 1984. "Industrial development and labor absorption: a reinterpretation," Population and Development Review 10: 589-611.

Portes, Alejandro and Richard Schauffler. 1993. "Competing perspectives on the Latin American informal sector," Population and Development Review 19: 33-60.

Preston, Samuel H. 1980. "Causes and consequences of mortality declines in developing countries during the twentieth century," in Richard A. Easterlin (ed.), Population and Economic Change in Developing Countries. Chicago: University of Chicago Press.

Preston, Samuel H. 1984. "Children and the elderly: divergent paths for America's dependents," Demography 21: 435-457.

Pritchett, Lant. 1997. Review of Robert D. Kaplan's The Ends of the Earth, Finance and Development, March, p. 51.

Prunier, Gérard. 1995. The Rwanda Crisis: History of a Genocide. New York: Columbia University Press.

Putnam, Robert D. 1993. Making Democracy Work: Civic Traditions in Modern Italy. Princeton: Princeton University Press.

Ravallion, Martin, Gaurav Datt, and Dominique van de Walle. 1991. "Quantifying absolute poverty in the developing world," Review of Income and Wealth 37, no. 4: 345-361.

Repetto, Robert. 1982. "Income redistribution and fertility decline: a reply," Population and Development Review 8 (Supplement): 174-178.

Rodgers, Gerry. 1984. Population and Poverty. Geneva: International Labour Office.

Rodgers, Gerry (ed.). 1989. Population Growth and Poverty in Rural South Asia. New Delhi: Sage. 
Rodgers, Gerry (ed.). 1995. New Approaches to Poverty Analysis and Policy. Geneva: ILO.

Rodgers, Gerry, Shaibal Gupta, Alakh N. Sharma, and Bachhoo Sharma. 1989. "Demographic patterns and poverty among households in rural Bihar," in Rodgers (1989).

Rodman, Hyman. 1968. "Class culture," in International Encyclopedia of the Social Sciences, Vol. 15, pp. 332-337.

Ruggles, Patricia. 1990. Drawing the Line: Alternative Poverty Measures and Their Implications for Public Policy. Washington, D.C.: Urban Institute Press.

Sachs, Ignacy. 1990. "Growth and poverty: some lessons from Brazil," in Drèze and Sen (1990), Vol. 3.

Scheper-Hughes, Nancy. 1992. Death Without Weeping: The Violence of Everyday Life in Brazil. Berkeley: University of California Press.

Seddon, David. 1989. “Population and poverty in Nepal," in Rodgers (1989).

Sen, Amartya. 1981. Poverty and Famines. Oxford: Oxford University Press.

Sen, Amartya. 1987. The Standard of Living. Cambridge: Cambridge University Press.

Sen, Amartya. 1990. "Food, economics, and entitlements," in Drèze and Sen (1990), Vol. 1.

Sen, Amartya. 1992. Inequality Reexamined. Oxford: Clarendon Press.

Shaffer, Paul. 1996. "Beneath the poverty debate: some issues," IDS Bulletin 27, no. 1: 23-35.

Solow, Robert M. 1970. Growth Theory: An Exposition. Oxford: Oxford University Press. 
Sowell, Thomas. 1983. The Economics and Politics of Race: An International Perspective. New York: Morrow.

Squire, Lyn. 1993. "Fighting poverty," American Economic Review 83: 377 382.

Timmer, C. Peter. 1994. "Population, poverty, and policies," American Economic Review 84 (Papers and Proceedings): 261-265.

United Nations Development Programme. 1996. Human Development Report 1996. New York: Oxford University Press.

United Nations Development Programme. 1997. Human Development Report 1997. New York: Oxford University Press.

United Nations Population Fund. 1993. Population Growth and Economic Development: Report on the Consultative Meeting of Economists Convened by the United Nations Population Fund 28-29 September 1992. New York.

U.S. National Research Council. 1986. Population Growth and Economic Development: Policy Questions. Washington, D.C.: National Academy Press.

Visaria, Pravin. 1980. "Poverty and living standards in Asia," Population and Development Review 6: 189-223.

Wood, Charles H. and Stephen G. Perz. 1996. "Population and land-use changes in the Brazilian Amazon," in Shridath Ramphal and Steven W. Sinding (eds.), Population Growth and Environmental Issues. Westport, CT: Praeger.

World Bank. 1993. World Development Report 1993. New York: Oxford University Press. 


\title{
POLICY RESEARCH DIVISION WORKING PAPERS
}

\author{
Recent Back Issues
}

1995

* 70 Sajeda Amin, John Cleland, James F. Phillips, and Gholam Mostafa Kamal, "Socioeconomic change and the demand for children in rural Bangladesh."

71 John Bongaarts, "The role of family planning programs in contemporary fertility transitions."

72 Geoffrey McNicoll, "On population growth and revisionism: Further questions."

73 James F. Phillips, Mian Bazle Hossain, and Mary Arends-Kuenning, "The longterm demographic role of communitybased family planning in rural Bangladesh."

74 Cynthia B. Lloyd, "Household structure and poverty: What are the connections?"

75 Sajeda Amin, "The poverty-purdah trap in rural Bangladesh: Implications for women's roles in the family."

76 Martin Brockerhoff, "Child mortality in East Africa: The impact of preventive health care."
77 Thomas K. LeGrand and James F. Phillips, "The effect of fertility reductions on infant and child mortality: Evidence from Matlab in rural Bangladesh."

78 Cynthia B. Lloyd and Ann K. Blanc, "Children's schooling in sub-Saharan Africa: The role of fathers, mothers, and others."

79 Geoffrey McNicoll, "Demography in the unmaking of civil society."

80 John Bongaarts, "Global trends in AIDS mortality."

81 Barbara Mensch, Mary ArendsKuenning, Anrudh Jain, and María Rosa Garate, "Meeting reproductive goals: The impact of the quality of family planning services on unintended pregnancy in Peru."

82 Mark Montgomery, Aka Kouamé, and Raylynn Oliver, "The tradeoff between the number of children and their schooling: Evidence from Côte d'Ivoire and Ghana." 
83 Sajeda Amin, Ian Diamond, and Fiona Steele, "Contraception and religious practice in Bangladesh."

84 John B. Casterline, Aurora E. Perez, and Ann E. Biddlecom, "Factors underlying unmet need for family planning in the Philippines."

85 Geoffrey McNicoll, "Governance of fertility transition: Regularity and duress."

86 John Bongaarts, "Population pressure and the food supply system in the developing world."

87 Sajeda Amin, "Family structure and change in rural Bangladesh."

88 John Bongaarts and Susan Cotts Watkins, "Social interactions and contemporary fertility transitions."
89 Cynthia B. Lloyd and Mark R. Montgomery, "The consequences of unintended fertility for investments in children: Conceptual and methodological issues."

* 90 Zeba Sathar and Sonalde Desai, "Work patterns in rural Pakistan: Intersections between gender, family, and class."

* 91 Mark R. Montgomery, "Learning and lags in mortality perceptions."

92 Ann E. Biddlecom, John B. Casterline, and Aurora E. Perez, "Men's and women's views of contraception."

* No longer available 
93 James F. Phillips, Fred N. Binka, Martin Adjuik, Alex Nazzar, and Kubaze Frank Adazu, "The determinants of contraceptive innovation: A case-control study of family planning acceptance in a traditional African society."

94 John Bongaarts and Sajeda Amin, "Prospects for fertility decline and implications for population growth in South Asia."

95 Barbara S. Mensch and Cynthia B. Lloyd, "Gender differences in the schooling experiences of adolescents in low-income countries: The case of Kenya."

96 Martin Brockerhoff and Ellen Brennan, "The poverty of cities in the developing world."

97 Carol E. Kaufman, "Reproductive control in South Africa."

98 John Bongaarts, "Trends in unwanted childbearing in the developing world."

99 Mary Arends-Kuenning, "How do family planning workers' visits affect wom- en's contraceptive behavior in Bangladesh?'

100 Mark R. Montgomery and Cynthia B. Lloyd, "Excess fertility, unintended births, and children's schooling.'

101 Mary Arends-Kuenning, "The equity and efficiency of doorstep delivery of contraceptives in Bangladesh."

102 Sajeda Amin, Ian Diamond, Ruchira T. Naved, and Margaret Newby, "Transition to adulthood of female factory workers: Some evidence from Bangladesh."

103 Margaret E. Greene and Ann E. Biddlecom, "Absent and problematic men: Demographic accounts of male reproductive roles."

104 Michael P. Todaro, "Urbanization, unemployment, and migration in Africa: Theory and policy."

105 Geoffrey McNicoll, "Population and poverty: A review and restatement." 